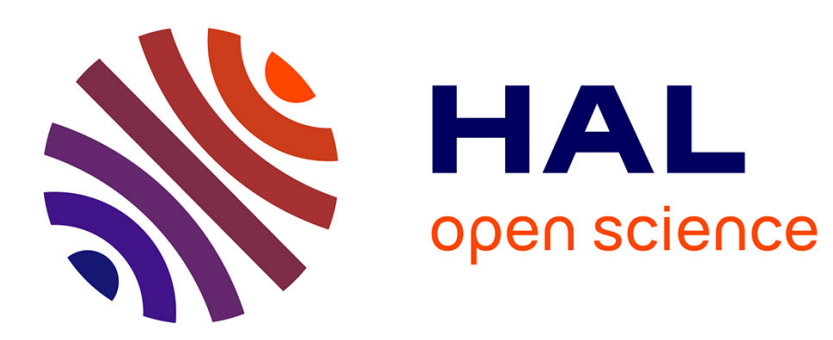

\title{
Volcanic Output of Long-Lived Radon Daughters
}

G. Lambert, B. Ardouin, G. Polian

\section{To cite this version:}

G. Lambert, B. Ardouin, G. Polian. Volcanic Output of Long-Lived Radon Daughters. Journal of Geophysical Research, 1982, 87 (C13), pp.11103. 10.1029/JC087iC13p11103 . hal-03511896

\section{HAL Id: hal-03511896 https://hal.science/hal-03511896}

Submitted on 5 Jan 2022

HAL is a multi-disciplinary open access archive for the deposit and dissemination of scientific research documents, whether they are published or not. The documents may come from teaching and research institutions in France or abroad, or from public or private research centers.
L'archive ouverte pluridisciplinaire HAL, est destinée au dépôt et à la diffusion de documents scientifiques de niveau recherche, publiés ou non, émanant des établissements d'enseignement et de recherche français ou étrangers, des laboratoires publics ou privés. 


\title{
Volcanic Output of Long-Lived Radon Daughters
}

\author{
G. Lambert, ${ }^{1}$ B. Ardouin, and G. Polian ${ }^{2}$ \\ Centre des Faibles Radioactivités, Laboratoire Mixte CNRS-CEA \\ 91190 Gif-sur-Yvette, France
}

\begin{abstract}
The concentrations of long-lived radon daughters have been measured in the exhausts of 11 volcanoes throughout the world. More particularly, the ${ }^{210} \mathrm{Po}$ activities measured were $10^{5}-10^{6}$ times higher than in a typical atmosphere. A total volcanic ${ }^{210} \mathrm{Po}$ output of $5 \times 10^{4} \mathrm{Ci} / \mathrm{yr}$ can be estimated by balancing the total deposition $\left(9 \times 10^{4} \mathrm{Ci} / \mathrm{yr}\right)$, the atmospheric production $\left(3 \times 10^{4} \mathrm{Ci} / \mathrm{yr}\right)$, and the other extra sources $\left(1 \times 10^{4} \mathrm{Ci} / \mathrm{yr}\right)$ of this nuclide. Therefore it seems possible to normalize the volcanic production of volatile elements to this ${ }^{210}$ Po output.
\end{abstract}

In our preceding papers [Lambert et al., 1976; Polian and Lambert, 1979] it has been shown that the plumes of the volcanoes Mt. Etna and Mt. Erebus are very rich not only in gaseous ${ }^{222} \mathrm{Rn}$ but also in radon decay products, including its long-lived daughters ${ }^{210} \mathrm{~Pb},{ }^{210} \mathrm{Bi}$, and ${ }^{210} \mathrm{Po}$ (Figure 1). This is attributed to the existence of volatile compounds of lead, bismuth, and polonium outgassed from the hot magma. Since these preliminary studies, nine other volcanoes have been analyzed. On the whole, the results shown in Table 2 definitely confirm our first conclusions.

The method of measurement, detailed elsewhere [Polian and Lambert, 1979], consists of filtering the cold mixture of air and volcanic gases through a cellulose fiber filter and then measuring its $\alpha$ and $\beta$ radioactive decays. The $\beta$-counting efficiency is measured by reference to a ${ }^{40} \mathrm{~K}$ source. The $\alpha$ counting efficiency is determined by comparing the $\alpha$ and $\beta$ activities of short-lived radon daughters sampled in the atmosphere to their theoretical ratio.

A possible error could arise from the fact that the condensation of the radon daughters occurs above $300^{\circ} \mathrm{C}$, as shown by Le Roulley et al. [1982], and therefore at a temperature higher than the dew point for sulfur and water vapor. In the case of fumaroles it was shown [Le Roulley et al., 1982] that the plume is oversaturated with sulfur vapor, which condenses on any possible condensation nuclei. Consequently, every aerosol grain is quickly coated with a sulfur deposit several micrometers thick, which absorbs the $\alpha$ rays.

On the other hand, in the case of magmatic gases the amount of dusts and aerosols in the plume is quite sufficient to avoid this last process, and the $\alpha$ counting efficiency is consistent with the results obtained by the method described above. This can be checked by comparing the $\alpha$ and $\beta$ counting rates of filters sampled at a date old enough to let ${ }^{210} \mathrm{Bi}$ and ${ }^{210} \mathrm{Po}$ be in radioactive equilibrium with their long-lived precursor ${ }^{210} \mathrm{~Pb}$ (see Table 1).

\section{VolCanic EMISSION of ${ }^{210} \mathrm{~PB}$}

The ${ }^{210} \mathrm{~Pb}$ activity is indicated in Table 2 for 16 volcanic sources from 11 volcanoes. It ranges between 0.03 and 684 $\mathrm{dpm} / \mathrm{m}^{3}$ of gas. In fact, the studied gases are made by sponta-

\footnotetext{
${ }^{1}$ Also at University of Picardie, St. Quentin, France.

${ }^{2}$ Also at ORSTOM-TAAF, Paris, France.

Copyright 1982 by the American Geophysical Union.
}

neous mixing of the volcanic emissions with the cold ambient air. Therefore the largest part of registered activity variations can be attributed to a more or less intense dilution. Over the continents the ${ }^{210} \mathrm{~Pb}$ specific activity, due to the disintegration of atmospheric ${ }^{222} \mathrm{Rn}$, is generally between $2 \times 10^{-4}$ and $6 \times 10^{-2} \mathrm{dpm} / \mathrm{m}^{3}$ of air with a mean value of the order of $4 \times 10^{-2} \mathrm{dpm} / \mathrm{m}^{3}$ [Lambert et al., 1982]. Consequently, the activities measured in the volcanic plumes, even diluted, are generally greater, by 1 or more orders of magnitude, than the atmospheric values.

In June 1980 the volcanic gases emitted from Bocca Nuova and the S.E. crater of Etna were sampled simultaneously by us for measuring radon daughters and by Patterson's and Buat-Ménard's teams for measuring the total lead (and other volatile elements). The results are compared in Table 3. They show that the specific activity of ${ }^{210} \mathrm{~Pb}$ ranges from $0.5 \times 10^{6}$ to $1 \times 10^{6} \mathrm{dpm} / \mathrm{g}$ of lead. In the Etna magma, both equivalent uranium and lead contents are of the order of $5 \mathrm{ppm}$, which corresponds to a ${ }^{210} \mathrm{~Pb}$ specific activity of $0.8 \times 10^{6} \mathrm{dpm} / \mathrm{g}$ of lead. (Equivalent uranium means the uranium amount corresponding to the radioactive equilibrium with ${ }^{226} \mathrm{Ra}$ nuclide which is actually measured.)

It seems therefore that despite the radiogenic production of ${ }^{210} \mathrm{~Pb}$ from a gaseous nuclide $\left({ }^{222} \mathrm{Rn}\right)$, the behaviors of the different lead isotopes are very similar. In conclusion, a good order of magnitude for the volcanic output of lead could be inferred from ${ }^{210} \mathrm{~Pb}$ flux measurements together with the magma composition in ${ }^{226} \mathrm{Ra}$ and total lead.

It will be shown further that the ${ }^{210}$ Po volcanic output should be about $5 \times 10^{4} \mathrm{Ci} / \mathrm{yr}$, corresponding to about 1.2 $\times 10^{3} \mathrm{Ci}$ or $2.5 \times 10^{15} \mathrm{dpm}$ of ${ }^{210} \mathrm{~Pb}$, with an average ${ }^{210} \mathrm{Po} /{ }^{210} \mathrm{~Pb}$ activity ratio of 40 . A specific activity of $0.8 \times 10^{6}$ $\mathrm{dpm} / \mathrm{g}$ would correspond to $3 \times 10^{3}$ tons $\mathrm{Pb} / \mathrm{yr}$, which is close to the values estimated by Patterson and Settle $[1981]\left(1 \times 10^{3}\right.$ $\mathrm{t} / \mathrm{yr})$ and Arnold et al. [1981] $\left(2 \times 10^{3} \mathrm{t} / \mathrm{yr}\right)$, who utilized a different method based on a normalization to the sulfur output.

\section{VolCANIC EMISSION OF ${ }^{210}$ Po}

The results of ${ }^{210} \mathrm{Po}$ measurements, listed in Table 2, range from 0.9 to $5800 \mathrm{dpm} / \mathrm{m}^{3}$. As for ${ }^{210} \mathrm{~Pb}$, this scatter is accounted for principally by the dilution of the volcanic gases by the ambient air. However, it may be pointed out that the activity ratio ${ }^{210} \mathrm{Po} /{ }^{210} \mathrm{~Pb}$ varies also between 0.6 and 400 : such a variation is only due to volcanic causes, not yet always understood.

Most of the sampled volcanic sources yield a ${ }^{210} \mathrm{Po} /{ }^{210} \mathrm{~Pb}$ ratio between 10 and 100 , the most likely ratio being close to 


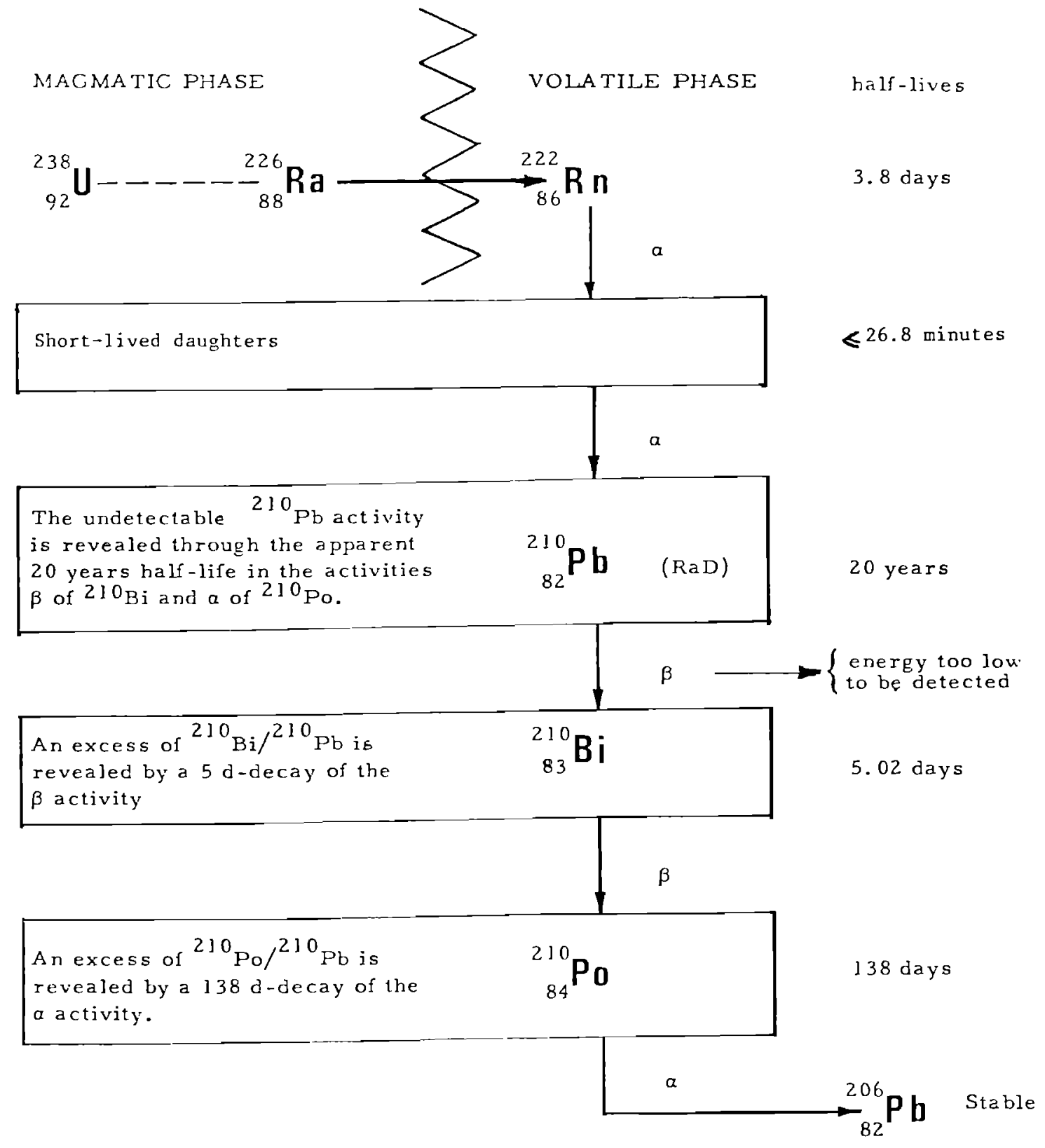

Fig. 1. Radon 222 decay series.

40. The values over 100 correspond generally to emissions at moderate temperatures, for which the polonium is still volatile but not the lead compounds. The very small values obtained at Etna in Yellow Crater and during the eruption of March 21, 1981, could be explained by the using up of the whole gaseous phase along the path between the magma reservoir and these remote secondary craters, according to G. Lambert et al. (unpublished manuscript, 1982).

By comparison to volcanic emissions the typical ${ }^{210} \mathrm{Po}$ activities measured in the atmosphere appear extremely low: generally between $1 \times 10^{-3}$ and $5 \times 10^{-3} \mathrm{dpm} / \mathrm{m}^{3}$, with a ${ }^{210} \mathrm{Po} /{ }^{210} \mathrm{~Pb}$ activity ratio of the order of 0.1 , that is, 400 times lower than in volcanic gases. Thus a moderately diluted volcanic source can typically be $10^{5}-10^{6}$ times richer in ${ }^{210}$ Po than the ambient atmosphere.

It is therefore not surprising that volcanic plumes can be detected by this ${ }^{210}$ Po content even at a very large distance from volcanoes. Lambert et al. [1979] observed at Dumont d'Urville station (Terre Adélie coast) ${ }^{210} \mathrm{Po} /{ }^{210} \mathrm{~Pb}$ activity ratios greater than 1 (above equilibrium) which are attributed to emissions from Mt. Erebus, $2000 \mathrm{~km}$ away. M. Arnold (private communication, 1980) identified by the same method the plume of Mt. Etna in the vicinity of Tunis, $300 \mathrm{~km}$ away. It was also pointed out by Lambert et al. [1982] that the ${ }^{210} \mathrm{Po} /{ }^{210} \mathrm{~Pb}$ activity ratio varies sharply from 0.14 to 0.43 when the atmospheric aerosols are sampled in the Coral Sea, leeward of the numerous active volcanoes of the Solomon and New Hebrides island arc. A similar result has been obtained by J.-C. Le Roulley (private communication, 1982), who measured in September 1981 at $20 \mathrm{~km}$ leeward of the modest emission of Mt. St. Helens the following atmospheric concentrations: ${ }^{210} \mathrm{~Pb}, 0.3 \mathrm{dpm} / \mathrm{m}^{3} ;{ }^{210} \mathrm{Bi}, 19 \mathrm{dpm} / \mathrm{m}^{3} ;{ }^{210} \mathrm{Po}, 14.6 \mathrm{dpm} / \mathrm{m}^{3}$, values which are typical of a volcanic plume.

In conclusion, it seems possible to use the high ${ }^{210}$ Po vol- 
TABLE 1. Measure of the ${ }^{210} \mathrm{Po} /{ }^{10} \mathrm{~Pb}$ Activity Ratios

\begin{tabular}{|c|c|c|c|}
\hline Sample & $\begin{array}{c}{ }^{210} \mathrm{Po} /{ }^{210} \mathrm{~Pb} \\
\text { at the } \\
\text { Sampling } \\
\text { Date }\end{array}$ & $\begin{array}{c}{ }^{210} \mathrm{Po} /{ }^{210} \mathrm{~Pb} \\
\text { Activity } \\
\text { Ratio } \\
\text { Calculated } \\
\text { in May } \\
1981\end{array}$ & $\begin{array}{c}{ }^{210} \mathrm{Po} /{ }^{210} \mathrm{~Pb} \\
\text { Activity } \\
\text { Ratio } \\
\text { Measured } \\
\text { in May } \\
1981\end{array}$ \\
\hline \multicolumn{4}{|c|}{ Erebus } \\
\hline \multicolumn{4}{|l|}{ Jan. 1978} \\
\hline 1 & 24.6 & 1.06 & 1.2 \\
\hline 2 & 26 & 1.07 & 1.1 \\
\hline 3 & 29.2 & 1.07 & 1.25 \\
\hline 4 & 28.2 & 1.07 & 1.2 \\
\hline 5 & 30.3 & 1.07 & 1.35 \\
\hline 6 & 28.1 & 1.07 & 1.3 \\
\hline 7 & 28.1 & 1.06 & 1.1 \\
\hline 8 & 28.6 & 1.07 & 1.35 \\
\hline \multicolumn{4}{|c|}{ Etna } \\
\hline June 1978 & & & \\
\hline Bocca Nuova & 8.3 & 1.05 & 0.7 \\
\hline NE crater & 9.1 & 1.04 & 1.0 \\
\hline \multicolumn{4}{|l|}{ June 1976} \\
\hline \multicolumn{4}{|l|}{ NE crater } \\
\hline 2 & 8.9 & 1.00 & 0.9 \\
\hline 3 & 12.2 & 1.00 & 0.6 \\
\hline 10 & 11.8 & 1.00 & 0.6 \\
\hline 11 & 8.4 & 1.00 & 0.75 \\
\hline 21 & 10.9 & 1.00 & 0.7 \\
\hline
\end{tabular}

canic injections to characterize the presence of volcanic emissions and possibly to measure the dilution of a volcanic plume at various distances from the crater.

\section{Evaluation of THE ${ }^{210}$ Po Volcanic OUTPUT}

Taking into account the extremely high ${ }^{210} \mathrm{Po}$ concentration in volcanic exhausts, relative to the atmosphere, the question can be asked whether the volcanic output is a significant part of the budget of this nuclide.

Lambert et al. [1979] normalized the ${ }^{210} \mathrm{Po}$ production in reference to a $\mathrm{SO}_{2}$ emission of $1 \times 10^{7} \mathrm{t} / \mathrm{yr}$, indicated by Stoiber and Jepsen [1973]. The ${ }^{210} \mathrm{Po}$ injection was thus estimated to be between $4 \times 10^{4}$ and $5 \times 10^{5} \mathrm{Ci} / \mathrm{yr}$.

Another possible approach could consist of balancing by extra sources the global deposition of ${ }^{210} \mathrm{Po}$ and its atmospheric production from ${ }^{210} \mathrm{Bi}$. However, two preliminary considerations show the inherent difficulties:

1. These extra sources are henceforth estimated by difference between two fluxes, which have therefore to be known with good accuracy.

2. We have to take into account the existence of a significant and unknown ${ }^{210} \mathrm{Po}$ flux from the stratosphere to the troposphere.

Owing to the large difference between the aerosol residence times in the troposphere and in the stratosphere, it was necessary to work out a two-box model. In each of these two reservoirs we assume the existence of a steady state. Therefore the production of a nuclide by radioactive decay of its precursor is balanced simultaneously by its own radioactivity and by the flux of atoms transferred to or from the other reservoir. In the case of the troposphere the budget is completed by (1) a global injection of ${ }^{222} \mathrm{Rn}$ from the surface of the continents and (2) an aerosol scavenging by a first-order process, therefore characterized by a constant $\lambda_{t}$, assumed to be identical for all the submicrometer aerosols, that is, more particularly the ${ }^{222} \mathrm{Rn}$ decay products.
Both these parameters are unknown and have to be calculated in the model. However, the residence time of the aerosols being of the order of a few days, it is clear that as far as the whole troposphere is concerned, the total amount of short-lived radon daughters is practically in radioactive equilibrium with the total amount of ${ }^{222} \mathrm{Rn}$, so that they can be completely neglected in what follows. The complete equations are as follows:

Troposphere

$$
\begin{aligned}
E+\vartheta_{\mathbf{R n}_{\mathrm{n}}} & =\lambda_{\mathbf{R n}} N_{\mathrm{Rn}_{\mathrm{n}}}+\phi_{\mathrm{Rn}} \\
\lambda_{\mathrm{Rn}} N_{\mathrm{Rn}}+\vartheta_{\mathrm{Pb}} & =\left(\lambda_{\mathrm{Pb}}+\lambda_{\imath}\right) N_{\mathrm{Pb}}+\phi_{\mathrm{Pb}} \\
\lambda_{\mathrm{Pb}} N_{\mathrm{Pb}}+\vartheta_{\mathrm{Bi}} & =\left(\lambda_{\mathrm{Bi}}+\lambda_{t}\right) N_{\mathrm{Bi}}+\phi_{\mathrm{Bi}} \\
\lambda_{\mathrm{Bi}} N_{\mathrm{Bi}}+\vartheta_{\mathrm{Po}} & =\left(\lambda_{\mathrm{Po}}+\lambda_{t}\right) N_{\mathrm{Po}}+\phi_{\mathrm{Po}_{0}}
\end{aligned}
$$

Stratosphere

$$
\begin{array}{r}
\phi_{\mathrm{Rn}}+\vartheta_{\mathrm{Rn}}{ }^{\prime}=\lambda_{\mathrm{Rn}} N_{\mathrm{Rn}}{ }^{\prime} \\
\lambda_{\mathrm{Rn}} N_{\mathrm{Rn}}{ }^{\prime}+\phi_{\mathrm{Pb}}+\vartheta_{\mathrm{Pb}}{ }^{\prime}=\lambda_{\mathrm{Pb}} N_{\mathrm{Pb}}{ }^{\prime} \\
\lambda_{\mathrm{Pb}} N_{\mathrm{Pb}}{ }^{\prime}+\phi_{\mathrm{Bi}}+\vartheta_{\mathrm{Bi}}{ }^{\prime}=\lambda_{\mathrm{Bi}} N_{\mathrm{Bi}}{ }^{\prime} \\
\lambda_{\mathrm{Bi}} N_{\mathrm{Bi}}{ }^{\prime}+\phi_{\mathrm{Po}}+\vartheta_{\mathrm{Pb}^{\prime}}=\lambda_{\mathrm{Po}} N_{\mathrm{Po}^{\prime}}
\end{array}
$$

where

$N_{\mathrm{R} n}, N_{\mathrm{Pb}}, N_{\mathrm{Bi}}, N_{\mathrm{Po}}$ total numbers of atoms of these nuclides present in the troposphere;

$\vartheta_{\mathrm{Rn}}, \vartheta_{\mathrm{Pb}}, \vartheta_{\mathrm{Bi}}, \vartheta_{\mathrm{Po}}$ numbers of atoms per time unit injected into the troposphere from the extra sources, mainly volcanoes (the same symbols primed relate to the stratosphere);

$\lambda_{\mathrm{Rn}}, \lambda_{\mathrm{Pb}}, \lambda_{\mathrm{Bi}}, \lambda_{\mathrm{Po}}$ radioactive constants;

$\lambda_{t}$ scavenging constant of the tropospheric aerosols;

$E$ number of ${ }^{222} \mathrm{Rn}$ atoms per time unit injected into the troposphere (essentially from the surface of the continents);

$\phi_{\mathrm{Rn}}, \phi_{\mathrm{Pb}}, \phi_{\mathrm{Bi}}, \phi_{\mathrm{Po}}$ numbers of atoms transferred from the troposphere into the stratosphere (a negative sign would correspond to the reverse transfer).

A complete treatment of these equations has been given elsewhere [Lambert et al., 1982]. It was admitted that $\vartheta_{\mathrm{Rn}}, \vartheta_{\mathrm{Pb}}$, $\vartheta_{\mathbf{R n}}{ }^{\prime}, \vartheta_{\mathrm{Pb}}{ }^{\prime}, \vartheta_{\mathrm{Bi}}{ }^{\prime}$, and $\phi_{\mathrm{Bi}}$ can be neglected. A critical step consisted of writing an equation of continuity at the tropopause level, which meant that the amount $F$ of air exchanged per unit time was equal in both senses, and it contained some amounts of each nuclide which were proportional to their mean concentrations $C$ and $C^{\prime}$, immediately below and above the tropopause:

$$
F=\frac{\phi_{\mathrm{Rn}}}{C_{\mathrm{Rn}}-C_{\mathrm{Rn}}{ }^{\prime}}=\frac{\phi_{\mathrm{Pb}}}{C_{\mathrm{Pb}}-C_{\mathrm{Pb}}{ }^{\prime}}=\frac{\phi_{\mathrm{Bi}}}{C_{\mathrm{Bi}}-C_{\mathrm{Bi}}{ }^{\prime}}=\frac{\phi_{\mathrm{Po}}}{C_{\mathrm{Po}}-C_{\mathrm{Po}^{\prime}}{ }^{\prime}}
$$

By using our own measurements as well as most of the data already published we have drawn up the following inventory:

Troposphere

$$
N_{\mathrm{Rn}}=4.4 \times 10^{23} \text { atoms }
$$


TABLE 2. Results of the ${ }^{210} \mathrm{~Pb},{ }^{210} \mathrm{Bi}$, and ${ }^{210} \mathrm{Po}$ Measurements in Volcanic Plumes

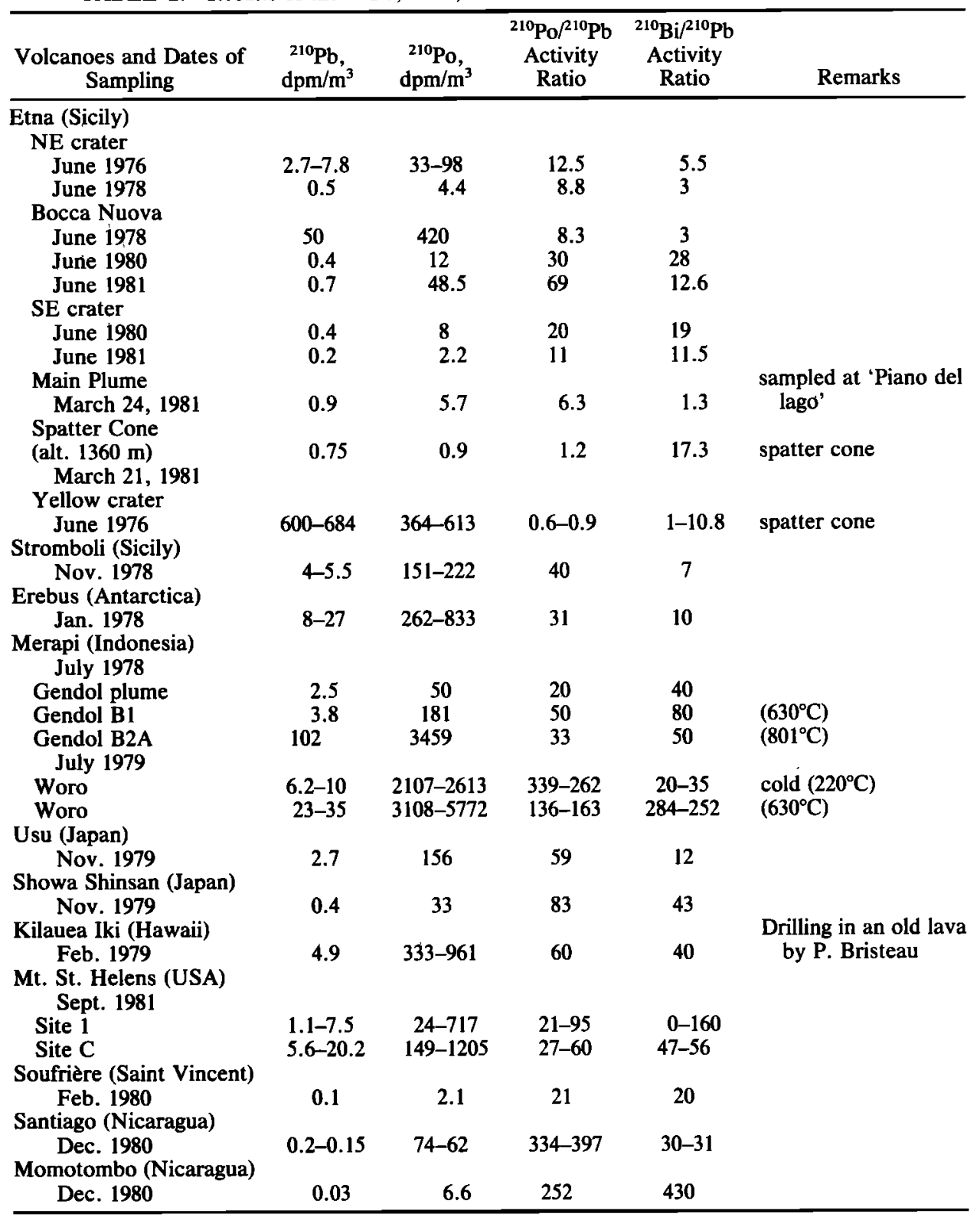

$$
\begin{aligned}
& N_{\mathrm{Pb}}=5.4 \times 10^{23} \text { atoms } \\
& N_{\mathrm{Bi}}=2.0 \times 10^{20} \text { atoms } \\
& N_{\mathrm{Po}}=1.0 \times 10^{21} \text { atoms }
\end{aligned}
$$

Stratosphere

$$
\begin{aligned}
& N_{\mathrm{R \Omega}}{ }^{\prime}=\text { unknown but low } \\
& N_{\mathrm{Pb}}{ }^{\prime}=2.3 \times 10^{23} \text { atoms } \\
& N_{\mathrm{Bi}}{ }^{\prime}=1.6 \times 10^{20} \text { atoms } \\
& N_{\mathrm{Po}^{\prime}}=2.3 \times 10^{21} \text { atoms }
\end{aligned}
$$

It is impossible to evaluate directly either the ${ }^{222} \mathrm{Rn}$ stratospheric reservoir or the concentration of this nuclide on both sides of the tropopause needed for evaluating the ${ }^{210}$ Po direct injection into the stratosphere $\left(\vartheta_{\mathrm{Po}}{ }^{\prime}\right)$ due to volcanic explosions.
This value is assumed to lie between 0 and $7 \times 10^{3} \mathrm{Ci} / \mathrm{yr}$. (This last value was previously obtained by Lambert et al. [1979] by

\begin{tabular}{|c|c|c|c|c|}
\hline & \multirow[b]{2}{*}{$\begin{array}{l}{ }^{210} \mathrm{~Pb} \\
\mathrm{dpm} / \mathrm{m}^{3}\end{array}$} & \multicolumn{2}{|c|}{ Total Lead, $10^{-9} \mathrm{~g} / \mathrm{m}^{3}$} & \multirow{2}{*}{$\begin{array}{c}\text { Mean } \\
\text { Specific } \\
\text { Activity of } \\
{ }^{210} \mathrm{~Pb}, \text { dpm } / \mathrm{g} \\
\text { of Lead }\end{array}$} \\
\hline & & $\begin{array}{c}\text { Arnold et al. } \\
{[1981]}\end{array}$ & $\begin{array}{c}\text { Patterson } \\
\text { and Settle } \\
{[1981]}\end{array}$ & \\
\hline $\begin{array}{l}\text { Bocca Nuova } \\
\text { SE crater }\end{array}$ & $\begin{array}{l}0.4 \\
0.4\end{array}$ & $\begin{array}{l}610 \\
370\end{array}$ & $\begin{array}{l}900 \\
450\end{array}$ & $\begin{array}{r}0.5 \times 10^{6} \\
1 \times 10^{6}\end{array}$ \\
\hline
\end{tabular}
normalization to the sulfur injection into the stratosphere.) Most of the results were therefore only known to be within a range of possible values. The entire model is summarized in Figure 2.

TABLE 3. Comparison of ${ }^{210} \mathrm{~Pb}$ and Total Lead at Etna in June 1980 


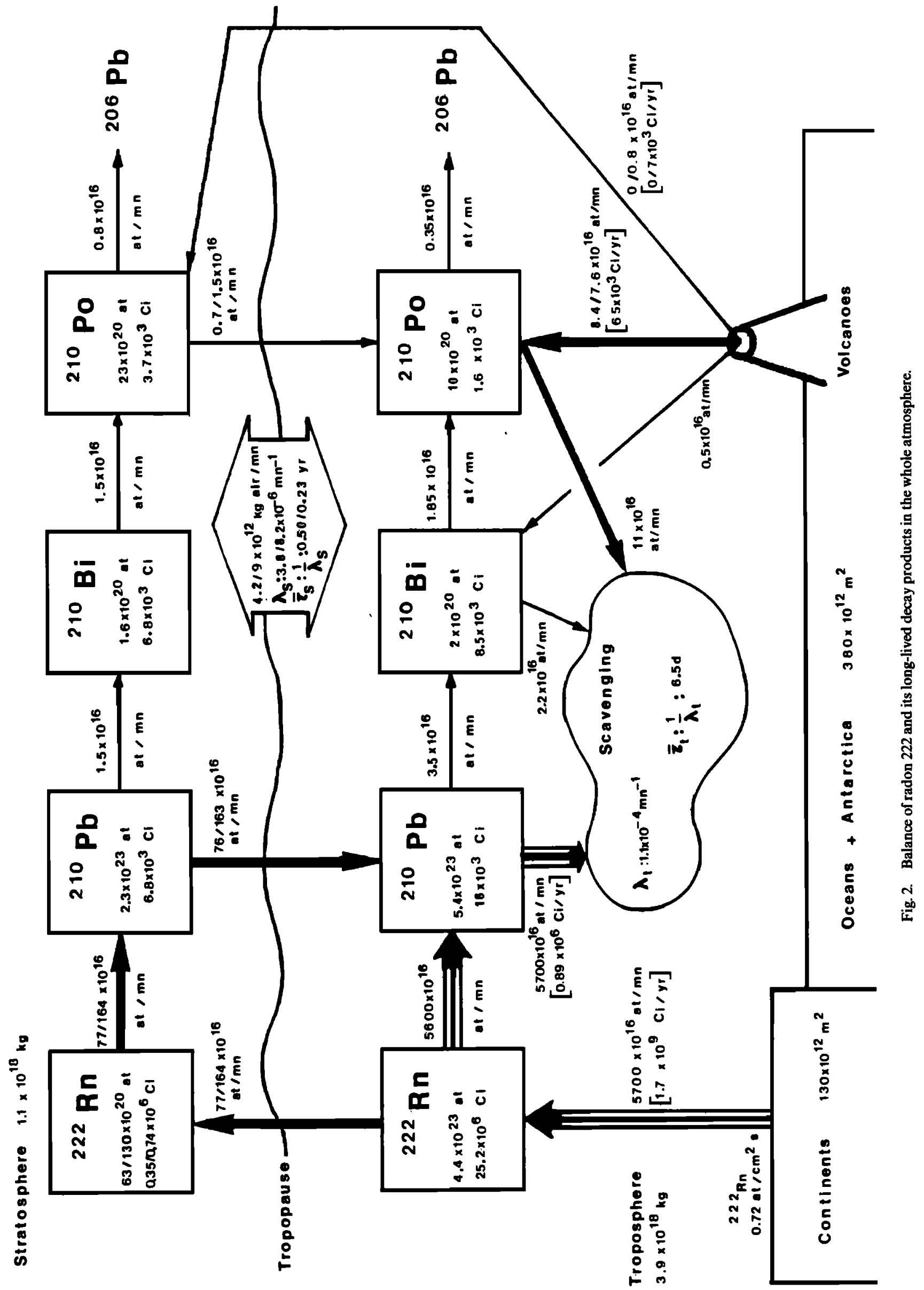


It has been checked that the results calculated in the model are self-consistent and generally agree well with the best figures previously accepted, for example, (1) the mean residence time of the aerosols in the troposphere is 6.5 days (5.9 days in the northern hemisphere, 8.8 in the southern hemisphere), (2) the ${ }^{222} \mathrm{Rn}$ emanation from the surface of the continents is 0.72 atoms $\mathrm{cm}^{-2} \mathrm{~s}^{-1}(0.71$ in the northern hemisphere, 0.72 in the southern hemisphere), and (3) the mean residence time of the air in the lower stratosphere is 3 to 6 months.

Concerning the ${ }^{210} \mathrm{Po}$ budget, it may be seen in Figure 2 that about $8 \times 10^{16}$ atoms $/ \mathrm{min}$, which corresponds to $4 \times 10^{22}$ atoms $/ y r$ or $6.5 \times 10^{4} \mathrm{Ci} / \mathrm{yr}$, have to be attributed to a source other than the atmospheric radioactivity. This extra source is therefore large enough to represent more than $70 \%$ of the total ${ }^{210} \mathrm{Po}$ production in the troposphere, evaluated to be $11.3 \times 10^{16}$ atoms $/ \mathrm{min}$, i.e., $9.3 \times 10^{4} \mathrm{Ci} / \mathrm{Yr}$. Only the volcanic source would be able to account for such a flux of ${ }^{210} \mathrm{Po}$.

Jaworowski et al. [1972] considered the emission of ${ }^{210} \mathrm{Po}$ by coal burning. The world coal consumption was $2.74 \times 10^{9}$ tons during 1980 [Revelle, 1981]. According to Bertine and Goldberg [1971] and McBride et al. [1978], the uranium content of coal is typically $1 \mathrm{ppm}$, i.e., $0.3 \mathrm{pCi} / \mathrm{g}$. Assuming the radioactive equilibrium ${ }^{238} \mathrm{U}-{ }^{210} \mathrm{Po}$, this source corresponds to about $1 \times 10^{3} \mathrm{Ci} / \mathrm{yr}$ of ${ }^{210} \mathrm{Po}$.

Turekian et al. [1974] showed that the zooplankton is generally enriched in ${ }^{210} \mathrm{Po}$ relative to ${ }^{210} \mathrm{~Pb}$ by about 1 order of magnitude. Therefore the marine aerosols from the surface layer of the oceans should be enriched in ${ }^{210} \mathrm{Po}$. Lambert et al. [1974] confirmed this possibility. However, Lambert et al. [1979] calculated a concentration limit range from $1 \times 10^{-4}$ to $4 \times 10^{-4} \mathrm{dpm} / \mathrm{m}^{3}$ of air for this marine ${ }^{210} \mathrm{Po}$. This range is about 10 times lower than the concentrations of $1 \times 10^{-3}$ to $5 \times 10^{-3} \mathrm{dpm} / \mathrm{m}^{3}$ typically measured in the atmosphere. Consequently, the maximum strength of the ${ }^{210} \mathrm{Po}$ marine source could be of the order of $1 \times 10^{4} \mathrm{Ci} / \mathrm{yr}$.

Finally, the volcanic output of ${ }^{210} \mathrm{Po}$ can be evaluated to be about $5 \times 10^{4} \mathrm{Ci} / \mathrm{yr}$, that is, $50-60 \%$ of the total production of this nuclide.

\section{CONCLUSION}

The processes of the emission of long-lived radon daughters from volcanoes is as yet far from being understood. In particular, ${ }^{210} \mathrm{Bi}$ seems to vary considerably from one source to another and, in a given crater, to vary with time. However, it is clear now that the concentration of these nuclides is always very rich in pure magmatic gases and can be utilized as a tracer for volcanic materials.

Owing to the rather short residence time of aerosols in the troposphere, the ${ }^{210} \mathrm{Po}$ concentration in volcanic plumes is thousands of times higher than in the ordinary atmosphere. This gives a method for measuring the dilution of plumes in space and time. Moreover, the fact that the volcanic output represents more than half the total input of this nuclide into the atmosphere enables us to use it as a reference for the other materials emitted by the active volcanoes. We have given such an example for the volcanic emission of lead. In the same way, and reversing our previous method of evaluation of the ${ }^{210} \mathrm{Po}$ volcanic source [Lambert et al., 1979], we can claim that the sulfur emission cannot be appreciably more important than the value of $1 \times 10^{7} \mathrm{t} / \mathrm{yr}$ of $\mathrm{SO}_{2}$ already accepted.

Acknowledgments. The authors thank P. Allard, P. Bourdon, P. Bristeau, A. Jegou, F. Le Guern, J.-C. Le Roulley, and J.-C. Sabroux for sampling on volcanoes. This work was supported by T.A.A.F. and P.I.R.P.S.E.V

\section{REFERENCES}

Arnold, M., P. Buat-Ménard, and R. Chesselet, An estimate of the input of trace metals to the global atmosphere by volcanic activity, paper presented at Symposium on the Role of Volcanic Emissions in Atmospheric Chemistry, Int. Assoc. of Meteorol. and Atmos. Phys., Hamburg, 1981.

Bertine, K. I., and E. D. Goldberg, Fossil fuel combustion and the major sedimentary cycle, Science, 173, 233-235, 1971.

Jaworowski, Z., J. Bilkiewicz, L. Kownacka, and S. Wlodek, Artificial sources of natural radionuclides in environment, in Natural Radiation Environment II, Conf. 720805 P2, pp. 809-818, U.S. ERDA, Houston, Tex., 1972

Lambert, G., J. Sanak, and B. Ardouin, Origine marine des excès de polonium 210 dans la basse atmosphère antarctique, J. Rech. Atmos., $8,647-648,1974$.

Lambert, G., P. Bristeau, and G. Polian, Emission and enrichments of radon daughters from Etna volcano magma, Geophys. Res. Lett., 3, 724-726, 1976

Lambert, G., A. Buisson, J. Sanak, and B. Ardouin, Modification of the atmospheric polonium 210 to lead 210 ratio by volcanic emissions, $J$. Geophys. Res., 84, 6980-6986, 1979.

Lambert, G., G. Polian, J. Sanak, B. Ardouin, A. Buisson, A. Jegou, and J.-C. Le Roulley, Cycle du radon et de ses descendants: Application à l'étude des échanges troposphère-stratospère, Ann. Geophys. $38,1982$.

Le Guern, F., J.-C. Le Roulley, and G. Lambert, Condensation du polonium dans les gaz volcaniques, C. R. Hebd. Seances Acad Sci., Ser. II, 294, 887-890, 1982.

McBride, J. P., R. E. Moore, J. P. Witherspoon, and R. E. Blanco, Radiological impact of airborne effluents of coal and nuclear plants, Science, 202, 1045-1050, 1978.

Patterson, C. C., and D. M. Settle, Magnitude of lead flux to the atmosphere from volcanoes, paper presented at Symposium on the Role of Volcanic Emissions in Atmospheric Chemistry, Int. Assoc. of Meteorol. and Atmos. Phys., Hamburg, 1981.

Polian, G., and G. Lambert, Radon daughters and sulfur output from Erebus volcano (Antarctica), J. Volcanol. Geotherm. Res., 6, 125-137, 1979.

Revelle, R., Paper presented at Symposium on Analysis and Interpretation of Atmospheric $\mathrm{CO}_{2}$ Data, World Meteorol. Organ., Bern, Sept. 1981.

Stoiber, R., and A. Jepsen, Sulfur dioxide contributions to the atmosphere by volcanoes, Science, 182, 577-578, 1973.

Turekian, K. K., D. P. Kharakar, and J. Thomson, The fates of ${ }^{210} \mathrm{~Pb}$ and ${ }^{210} \mathrm{Po}$ in the ocean surface, J. Rech. Atmos., 8, 639-646, 1974.

(Received February 5, 1982; revised May 4, 1982; accepted May 11, 1982.) 